強度の場合は如何にすべきか，と云う如き重大な且つ困難な問題が残つている。従来はこれらは単に視察踣びに 小試験片により評価された程度であつて，工学的な尺度によつて適確に判断される為には岩盤に対する力学的研 究站びに現地に於ける測定の接術が大いに進歩しなければならない。これ等の問題が解決される様になつて始め てダムの滑動の問題が全般的に解き得られる様になるのである。

附記 本交に述べた実験の実施にあたつて非常な学苦を惜しまれなかつた早稲田大学々生㻕川, 遠山の両君及 び当研究所の若本君に対し厚く謝意を表するるのである。

UDC 624.075 .4

\title{
多径間連続板の挫屈荷重の計算法
}

正員工学博士 含田 宗 章*

\section{A METHOD OF DETERMINATION OF THE CRITICAL LOADS OF THE CONTINUOUS REC'TANGULAR PLATES WITH MULTIPLE SPANS}

\author{
Dr. Eng., Muneaki Kurata, C.E., Member
}

\begin{abstract}
Synopsis The problems of elastic stability of the continuous columns with multiple equal spans have been conveniently solved by means of "Differenzengleichung".

In this paper, the author shows that the buckling problems of the continuous rectangular plates simply supported along the two opposite sides parallel to the direction of the multiple spans are solved in the same manner, moreover he derives the calculation formulae in the cases of various end conditions and illustrates those with numerical examples.

Finally, some considerations are delivered for practical applications.
\end{abstract}

要旨 等閒隔多径間連続長枉の軸圧力に依る挫屈の問題は Differenzengleichung に依り簡易に解決されてい、 る。同様なす法が径間方向の相対 2 辺が単純に交承された連続板に対しても適用される事を示し, 種々の端辺条 件に対する計算公式並びにそれが数值計算例を挙げ併せて実際の応用に対する三，三の所見を述べたるのである。

目次

序 㝘

1. 基礎階美方程式 2. 端辺条件式 3. 挫屈条件式４. 計算例

序言

等間隔多径間連続杜の挫屈荷重は Fr.Bleich に依つて所謂 3 連モーメントの公式を用いて Differenzengleichung として解く事に依り簡易に求められた。著者は上記連続杜を径間方向の相対 2 辺が単純支承された 連続板とした場合に対しても同様な取扱の可能なる事を示乞うと思う。沿本文中，随所に省略せる演算は著者の 旧著(建設工学，第2昂，p.27)を参照する事により容易に判明し得る部分である。

1. 基礎階差方程式

所題の連続板並びに座標亲は図一1の如くであるとする。第 $r$ 番目の径間部分につき中立面内の周辺直圧力を 受ける板の微分方程式は $w_{r}$ 党撓度とすれば

$$
\Delta \Delta w_{r}+\frac{p}{D} \frac{\partial^{2} w_{r}}{\partial x_{r}{ }^{2}}+\frac{q}{D} \frac{\partial^{2} w_{r}}{\partial y_{r}{ }^{2}}=0
$$

但し $\Delta=\frac{\partial^{2}}{\partial x^{2}}+\frac{\partial^{2}}{\partial y^{2}}:$ Laplace のオペレーター, $D=\frac{E h^{3}}{12\left(1-\nu^{2}\right)}$ : 板の曲け剛度

$E$ : young 率, $h$ : 板厚, $\nu$ : poisson 比

* 北海道大学敉授, 工学部土木工学呚室 


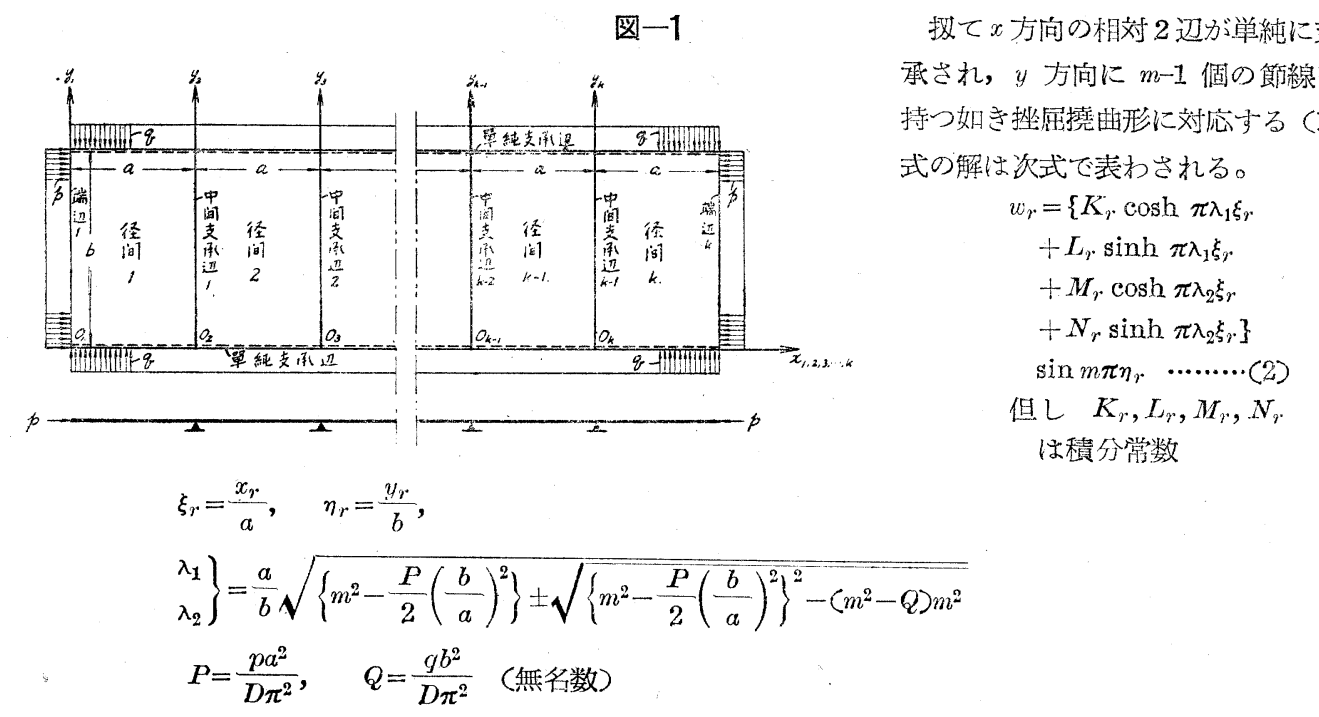

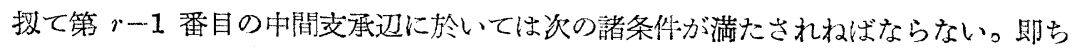

撓度は0である：

$$
\underset{\xi_{r-1}=1}{\left|w_{r-1}\right|=0, \quad\left|w_{r}\right|} \underset{\xi_{r}=0}{=0}=0,
$$

相隣る径間部分の角変位は連続する： $\quad\left|\frac{\partial w_{r-1}}{\partial x_{r-1}}\right|_{\xi_{r-1}=1}=\left|\frac{\partial w_{r}}{\partial x_{r}}\right|_{\xi_{r}=0}$

曲げモーメントは平衡する： $\quad\left|\frac{\partial^{2} w_{r-1}}{\partial x^{2} r-1}+\nu \frac{\partial^{2} w_{r-1}}{\partial y^{2} r-1}\right|_{\xi_{r-1}=1}=\left|\frac{\partial^{2} w_{r}}{\partial x_{r}^{2}}+\nu \frac{\partial^{2} w_{r}}{\partial y_{r}^{2}}\right|_{\xi_{r}=0}$

此等の条件式に(2)式を代入すれば

$K_{r-1} \cosh \pi \lambda_{1}+L_{r-1} \sinh \pi \lambda_{1}+M_{r-1} \cosh \pi \lambda_{2}+N_{r-1} \sinh \pi \lambda_{2}=0$,

$$
K_{r}+M_{r}=0
$$

$K_{r-1} \lambda_{1} \sinh \pi \lambda_{1}+L_{r-1} \lambda_{1} \cosh \pi \lambda_{1}+M_{r-1} \lambda_{2} \sinh \pi \lambda_{2}+N_{r-1} \lambda_{2} \cosh \pi \lambda_{2}-L_{r} \lambda_{1}-N_{r} \lambda_{2}=0$,

$K_{r-1} \beta_{1} \cosh \pi \lambda_{1}+L_{r-1} \beta_{1} \sinh \pi \lambda_{1}+M_{r-1} \beta_{2} \cosh \pi \lambda_{2}+N_{r-1} \beta_{2} \sinh \pi \lambda_{2}-K_{r} \beta_{1}-M_{r} \cdot \beta_{2}=0$,

茲に $\left.\left.\begin{array}{l}\beta_{1} \\ \beta_{2}\end{array}\right\}=\begin{array}{l}\lambda_{1}^{2} \\ \lambda_{2}{ }^{2}\end{array}\right\}-\nu\left(\frac{m a}{b}\right)^{2}$

上の第2式より $K_{r}=-M_{r}=B_{r}$ と扔くものとすれば， $K_{r-1}=-M_{r-1}=B_{r-1}$ と書けるから残りの 3 式を書き換 えると

$B_{r-1}\left(\cosh \pi \lambda_{1}-\cosh \pi \lambda_{2}\right)+L_{r-1} \sinh \pi \lambda_{1}+N_{r-1} \sinh \pi \lambda_{2}=0$,

$B_{r-1}\left(\lambda_{1} \sinh \pi \lambda_{1}-\lambda_{2} \sinh \pi \lambda_{2}\right)+L_{r-1} \lambda_{1} \cosh \pi \lambda_{1}+N_{r-1} \lambda_{2} \cosh \pi \lambda_{2}-L_{r} \lambda_{1}-N_{r} \lambda_{2}=0$,

$B_{r-1}\left(\beta_{1} \cosh \pi \lambda_{1}-\beta_{2} \cosh \pi \lambda_{2}\right)+L_{r-1} \beta_{1} \sinh \pi \lambda_{1}+N_{r-1} \beta_{2} \sinh \pi \lambda_{2}-B_{r}\left(\beta_{1}-\beta_{2}\right)=0$,

この第 1 式と第 3 式とより

$$
\left.\begin{array}{l}
L_{r-1}=-B_{r-1} \operatorname{coth} \pi \lambda_{1}+B_{r} \operatorname{cosech} \pi \lambda_{1} \\
N_{r-1}=B_{r-1} \operatorname{coth} \pi \lambda_{2}-B_{r} \cdot \operatorname{cosech} \pi \lambda_{2}
\end{array}\right\}
$$

これを第2式に入れると

$$
B_{r-1} S-B_{r} T+A_{r}=0
$$

但ᄂ $\left.S=\lambda_{1} \operatorname{cosech} \pi \lambda_{1}-\lambda_{2} \operatorname{cosech} \pi \lambda_{2}, T=\lambda_{1} \operatorname{coth} \pi \lambda_{1}-\lambda_{2} \operatorname{coth} \pi \lambda_{2}, A_{r}=L_{r} \lambda_{1}+N_{r} \lambda_{2}\right\}$

今 (3) 式に於て添数 $r-1$ の代りに $r$ と置いて得る式を用いれば

$$
A_{r}=L_{r} \lambda_{1}+N_{r} \lambda_{2}=-B_{r} T+B_{r+1} S .
$$

と書かれるから(4)式は次の如くなる

$$
B_{r-1} S-2 B_{r} T+B_{r+1} S=0
$$

従つて

$$
B_{r-1}-2 B_{r} \frac{T}{S}+B_{r+1}=0
$$

これは $B_{r}$ に関する 2 階の Symmetrische Differenzengleichung に他ならない。此の一般解は容易に求めら 
れて $C_{1}, C_{2}$ を新たな未定常数として次の如く表わされる。

$$
\begin{aligned}
& B_{r}=C_{1} \sin r \alpha+C_{2} \cos r \alpha \\
& \text { 但し } \quad \cos \alpha=\frac{T}{S}
\end{aligned}
$$

2. 端辺条件式

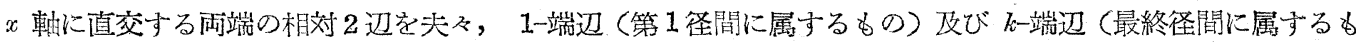
の）と仮称し，此等が単純交承辺，固定辽，或いは自由辺なる場合を考察する。然る時は夫々の場合に対する条 件式は次の如く書かれる。即ち $\xi_{1}=0, \xi_{k}=1$ なる時

i) 単純交承の場合

$$
\begin{aligned}
& w_{1}=0 \\
& \frac{\partial^{2} w_{1}}{\partial x_{1}{ }^{2}}+\nu \frac{\partial^{2} w_{1}}{\partial y_{1}{ }^{2}}=0
\end{aligned}
$$

$$
\left\{\begin{array}{l}
w_{k}=0 \\
\frac{\partial^{2} w_{k}}{\partial x_{k}{ }^{2}}+\nu \frac{\partial^{2} w_{k}}{\partial y_{k}{ }^{2}}=0
\end{array}\right.
$$

ii）固定の場合

$$
\left.\begin{array}{l}
w_{1}=0 \\
\frac{\partial w_{1}}{\partial x_{1}}=0
\end{array}\right\} \begin{aligned}
& w_{k}=0 \\
& \frac{\partial w_{k}}{\partial x_{k}}=0
\end{aligned}
$$

iii) 自由の場合

$$
\left.\left.\begin{array}{l}
\frac{\partial^{2} w_{1}}{\partial x_{1}^{2}}+\nu \frac{\partial^{2} w_{1}}{\partial y_{1}{ }^{2}}=0 \\
{\left[\frac{\partial^{3} w_{1}}{\partial x_{1}{ }^{3}}+(2-\nu) \frac{\partial^{3} w_{1}}{\partial x_{1} \partial y_{1}{ }^{2}}\right]+\frac{p}{D} \frac{\partial w_{1}}{\partial x_{1}}=0}
\end{array}\right\} \quad \begin{array}{l}
\frac{\partial^{2} w_{k}}{\partial x_{k}{ }^{2}}+\nu \frac{\partial^{2} w_{k}}{\partial y_{k}{ }^{2}}=0 \\
{\left[\frac{\partial^{3} w_{k}}{\partial x_{k}{ }^{3}}+(2-\nu) \frac{\partial^{3} w_{k}}{\partial x_{k} \partial y_{k}{ }^{2}}\right]+\frac{p}{D} \frac{\partial w_{k}}{\partial x_{k}}=0}
\end{array}\right\}
$$

此等の条件式に(2)式に於て $r=k$ と扔いて得る式を代入して $\xi_{k}=1$ と徰けば

\section{$k$-端辺条件式として}

i ) 単純支承辺の場合

$$
M_{k} \cosh \pi \lambda_{2}+N_{k} \sinh \pi \lambda_{2}=0, K_{k} \cosh \pi \lambda_{1}+L_{k} \sinh \pi \lambda_{1}=0
$$

を得るからこ机より

故に

$$
L_{k}=-K_{k} \operatorname{coth} \pi \lambda_{1}=-B_{k} \operatorname{coth} \pi \lambda_{1}, N_{k}=-M_{k} \operatorname{coth} \pi \lambda_{2}=B_{k} \operatorname{coth} \pi \lambda_{2}
$$

$$
A_{k}=L_{k} \lambda_{1}+N_{k} \lambda_{2}=-B_{k} T
$$

この式と(4)式に於て $r=k$ と扔いて得る式とより

$$
B_{k-1}-B_{k}\left(2 \frac{T}{S}\right)=0
$$

ii）固定辺の場合，前同様 $L_{k}, N_{k}$ を求め $A_{k}$ を $B_{k}$ で表わせば途中の演算を省略して1)

$$
A_{k}=-B_{k}\left(T-\frac{S^{2}}{T}\right)
$$

を得るから，(4) 式に於て $r=k$ と捻いて得る式とより

$$
B_{k-1}-B_{k}\left(2 \frac{T}{S}-\frac{S}{T}\right)=0
$$

iii）自由辺の場合, 此の場合子途中の演算を省略して2)

$$
\begin{aligned}
& A_{k}=-B_{k} \frac{T T^{\prime}-\bar{S} S^{\prime \prime}}{T^{\prime}}, \text { 但 } \quad T^{\prime}=\frac{\gamma_{1}+P \lambda_{1}}{\beta_{1}} \operatorname{coth} \pi \lambda_{1}-\frac{\gamma_{2}+P \lambda_{2}}{\beta_{2}} \operatorname{coth} \pi \lambda_{2} \\
& \bar{S}=\frac{\lambda_{1}}{\beta_{1}} \operatorname{cosech} \pi \lambda_{1}-\frac{\lambda_{2}}{\beta_{2}} \operatorname{cosech} \pi \lambda_{2}, S^{\prime \prime}=\left(\gamma_{1}+P \lambda_{1}\right) \operatorname{cosech} \pi \lambda_{1}-\left(\gamma_{2}+P \lambda_{2}\right) \operatorname{cosech} \pi \lambda_{2}
\end{aligned}
$$

茲に

$$
\left.\left.\left.\begin{array}{l}
\gamma_{1} \\
\gamma_{2}
\end{array}\right\}=\begin{array}{l}
\lambda_{1} \\
\lambda_{2}
\end{array}\right\}\left[\begin{array}{l}
\lambda_{1}^{2} \\
\lambda_{2}{ }^{2}
\end{array}\right\}-(2-\nu)\left(\frac{m a}{b}\right)^{2}\right]
$$

を得るから，上式と(4) 式に於て $r=k$ と置いて得る式とより

$$
B_{k-1}-B_{k}\left(2 \frac{T}{S}-\frac{\bar{S} S^{\prime \prime}}{S T^{\prime}}\right)=0
$$

1) 建設工学, 第 2 号, 拙著参照。2) 脚註 1) 參照。 
次に刎めに挙げた条件式に（2）式に於て $r=1$ と置いて得る式を代入して $\xi_{1}=0$ と招けば

1-端辺条件式として

i) 単純支承辺の場合 $\quad K_{1}+M_{1}=0, K_{1} \beta_{1}+M_{1} \beta_{2}=0$

を得るから，これより $K_{1}=-M_{1}=B_{1}=0$ 即ち $B_{1}=0$

ii）固定辺の場合 $\quad K_{1}+M_{1}=0, L_{1} \lambda_{1}+N_{1} \lambda_{1}=A_{1}=0$

故に上の第2式と $(4 a)$ 式とより $\quad B_{1}-B_{2} \frac{S}{T}=0$

iii）自由辺の場合，途中の演算を省略して $\left.{ }^{3}\right)$

$$
A_{2}=B_{2}\left(T-\frac{\bar{S} S^{\prime \prime}}{T^{\prime}}\right)
$$

を得るから(4)式に於て $r=2$ と置いて得る式とより $B_{1}-B_{2} \frac{\bar{S} S^{\prime \prime}}{S T^{\prime}}=0$

\section{3. 挫屈条件式}

次に一般解 (6) 前節の各端辺条件式に代入して整頓すれば夫々の場合につき次の各式を得る。

$k$-端辺単純交承の場合：(7)式より $C_{1} \sin (k+1) \alpha+C_{2} \cos (k+1) \alpha=0$

$k$-端辺固定の場合：(8)式より $C_{1} \cos (k+1) \alpha-C_{2} \sin (k+1) \alpha=0$

$k$-端辺自由の場合: (9)式より $C_{1}\left\{\sin (k+1) \alpha-\frac{\bar{S} S^{\prime \prime}}{S T^{\prime}} \sin k \alpha\right\}+C_{2}\left\{\cos (k+1) \alpha-\frac{\bar{S} S^{\prime \prime}}{S T^{\prime}} \cos k \alpha\right\}=0 \cdots$ (15) 1一端辺単純卖承の場合: (10)式上り, $C_{1} \sin \alpha+C_{2} \cos \alpha=0$

1-端辺固定の場合：(11)式より $C_{1} \cos \alpha-C_{2} \sin \alpha=0$.

1-端辺自由の場合：(12)式より

$$
C_{1}\left\{\sin \alpha-\frac{\bar{S} S^{\prime \prime}}{S T^{\prime}} \sin 2 \alpha\right\}+C_{2}\left\{\cos \alpha-\frac{\bar{S} S^{\prime \prime}}{S T^{\prime}} \cos 2 \alpha\right\}=0
$$

故に結局挫屈条件式は次の如く求められる。

a) 两端単純交承辺の場合 (13)式と(16)式とより $C_{1}, C_{2}$ を消去与れば

$$
\sin k \alpha=0
$$

b) 一端学純交承辺他端固定辺の場合 (13)式と(17)式，又は(14)式と(16)式とより $C_{1}, C_{2}$ を消去すれば

$$
\cos k \alpha=0
$$

c) 蛋端固定辺の場合（14)式と(17)式とより $C_{1}, C_{2}$ を消去すれば

$$
\sin k a=0
$$

d) 一端単純交承辺他端自由辺の場合 前同様(13)式と(18)式，又は(15)式と(16)式とから

$$
\frac{\bar{S} S^{\prime \prime}}{S T^{\prime}}=\frac{\sin k \alpha}{\sin (k-1) \alpha}
$$

e）一端固定辺他端自由辺の場合 (14)式と(18)式，又は(15)式と(17)式とから

$$
\frac{\bar{S} S^{\prime \prime}}{S T^{\prime}}=\frac{\cos k a}{\cos (k-1) \alpha}
$$

f）画端自由辺の場合 (15)式と(18)式とから $C_{1}, C_{2}$ を消去すれば

$$
\left(\frac{\bar{S} S^{\prime \prime}}{S T^{\prime}}\right)^{2} \sin (k-2) \alpha-2\left(\frac{S S^{\prime \prime}}{S T^{\prime}}\right) \sin (k-1) \alpha+\sin k \alpha=0
$$

これ快又

$$
\left\{\frac{\bar{S} S^{\prime \prime}}{S T^{\prime}}-\frac{\sin (k-1) \alpha+\sin \alpha}{\sin (k-2) \alpha}\right\}\left\{\frac{\bar{S} S^{\prime \prime}}{S T^{\prime}}-\frac{\sin (k-1) \alpha-\sin \alpha}{\sin (k-2) \alpha}\right\}=0
$$

と書かれるから結局次式を得る。

$$
\frac{\bar{S} S^{\prime \prime}}{S T^{\prime}}=\frac{\sin (k-1) \alpha \pm \sin \alpha}{\sin (k-2) \alpha}
$$

\section{4. 計 算 例}

次に具体的数値针算例を以つて上記各公式の使用法並びに二,三の検討を試みよう。先づ以下の計算例に於ては

3）脚註 1) 参照。 
すべて $\frac{a}{b}=\frac{1}{2}, \nu=0,3$ と仮定するものとする。

a) 雨端単純支承辺の場合 此の場合は(19)式より

從つて $\quad \alpha=s \frac{\pi}{k}, \quad(s=0,1,2,3, \cdots \cdots \cdots, 2 k-1)$

故に前出 (6)の第 2 式を参照すれば挫屈条件式は次の如く書かれる。

$$
\begin{aligned}
& \cos s \frac{\pi}{k}=\frac{T}{S}=\frac{\lambda_{1} \operatorname{coth} \pi \lambda_{1}-\lambda_{2} \operatorname{coth} \pi \lambda_{2}}{\lambda_{1} \operatorname{cosech} \pi \lambda_{1}-\lambda_{2} \operatorname{cosech} \pi \lambda_{2}} \\
& (s=0,1,2,3, \cdots \cdots \cdots, 2 k-1)
\end{aligned}
$$

今上式に於いて $b=\infty$ とした極限の場合を考えてみよう。此の時 $\lambda_{1}=0, \lambda_{2}=i \frac{Z}{\pi}$ 但し $Z=a \sqrt{\frac{p}{D}}$ となるから， 上式を書換えて

$$
\cos s \frac{\pi}{k}=\frac{\frac{\pi \lambda_{1}}{\sinh \pi \lambda_{1}} \cosh \pi \lambda_{1} \sinh \pi \lambda_{2}-\pi \lambda_{2} \cosh \pi \lambda_{2}}{\frac{\pi \lambda_{1}}{\sinh \pi \lambda_{1}} \sinh \pi \lambda_{2}-\pi \lambda_{2}}
$$

とし $\lambda_{1} \rightarrow 0, \pi \lambda_{2} \rightarrow i Z$ なる極限移行を施すと $\cos s \frac{\pi}{k}=\frac{\sin Z-Z \cos Z}{\sin Z-Z}$

となる。此れは等径間連続長杜の挫屈条件方程式に他ならないれ。而して両端鉸支承なる場合上式の最小根は $s=k$ と置いて $Z=\pi$ となる事が知られている5)。

先づ荷重条件として $p$ のみが作用する場合を考え る。上記連続長桂の場合に於ける結果を参照して $\left(19^{\prime}\right)$ 式に於いて $s=k$ と置いてみると左辺は $k$ 無関係にー1 となる。一方右辺 $\frac{T}{S}$ を $P$ の函数として図示し6て 括けば図一2に示寸如く丁度 $P=1.5625$ で(19’)の関 係が成立寸る事が解る7。然るに $P=1.5625$ は $\frac{a}{b}=\frac{1}{2}$ なる周辺単純交承の単一板の最小挫屈荷重を与えるる のに他ならない。此の結果を考察するに元来只今の如 き連続板にあつては各径間が夫々単一板として交互に 反対側に撓曲する場合が最も簡単な挫屈形式でありそ れは径間数に無関係に考兄られる形態である事を注意 すれば首学し得られる処である。

次に荷重 $q$ のが作用する場合を考光る。此の場合 も前と前様な挫屆形式が最小根に対応するであろう事 は想像に難くない。即ち各径間を夫々単一板の如く考 えればよい。只今の場合 $\frac{a}{b}=\frac{1}{2}$ であるから単一板と しては周知の如く $y$ 方向に一波長形に挫屈する場合が 最小挫屈荷重に対応し其の時 $Q=16$ である[因みにy方 向に半遮長形汇挫屈寸る場合は $Q=25]$ 。実際 $m=2$ と した場合の $\frac{T}{S}$ をの函数として図示すれば $Q$ の上 記の值で $\left(19^{\prime}\right)$ 式を満足する事加解る [図一3 参照]。

b) 一端固定辺他端単純支承辺の場合 此の場合は
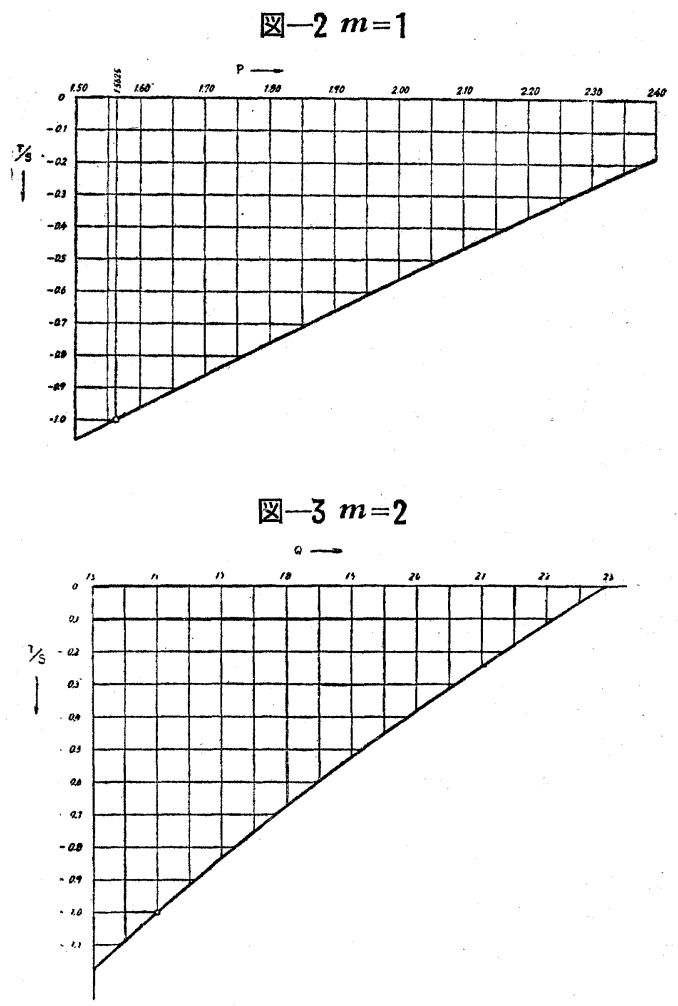
(20)式上り $\cos k \alpha=0$

4) Fr.Bleich und. E.Melan "Die Gewöhnlichen und Partiellen Differenzengleichungen der Baustatik" 1927, s.216.

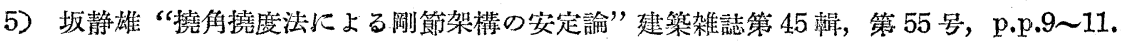

6) 只今の連続板に於て特に $k=1$ なる場合を考えれば,そ扎は周辺単純支承の単一板に他ならない。其の時 $P=$ 1.5625 であるから大体此の附近で $T / S$ を $P$ の函数として図示して和けばよい事が推察される。但し $m=1$ と和くものとする。

7) $\left(19^{\prime}\right)$ 式に直接 $P=1.5625$ を代入すれば $T / S=-\infty / \infty$ とな $y$ 不定形となる。然し只今の如く図式に認め られるととは $\lim _{P \rightarrow 1.5625}\left(\frac{T}{S}\right)=-1$ が成立する事に他ならない。 
これより

$$
\alpha=\left(s+\frac{1}{2}\right) \frac{\pi}{k},(s=0,1,2,3, \cdots \cdots \cdots, 2 k-1)
$$

故に前出 (6) 式を考慮すれば挫屈条件式は次の如く書かれる。

$$
\begin{aligned}
& \cos \left(s+\frac{1}{2}\right) \frac{\pi}{k}=\frac{T}{S}=\frac{\lambda_{1} \operatorname{coth} \pi \lambda_{1}-\lambda_{2} \operatorname{coth} \pi \lambda_{2}}{\lambda_{1} \operatorname{cosech} \pi \lambda_{1}-\lambda_{2} \operatorname{cosech} \pi \lambda_{2}} \\
& (s=0,1,2,3, \cdots \cdots \cdots, 2 k-1)
\end{aligned}
$$

双て $k=1$, 即ち単一板の場合には上式より次の関倸式を得る。

$$
\lambda_{1} \cosh \pi \lambda_{1}-\lambda_{2} \operatorname{coth} \pi \lambda_{2}=0
$$

これは既知の公式である8)。

执て, 先づ荷重 $p$ のみの作用する場合を考兄よ5。 $k=1$ の時は上述の如く(20")式を得て最小根は此の場合 $P=2.5966$ なる事が既知である。次に $k=\infty$ なる極限の場合を想像しよう。此の場合には Fr.Bleich が連続杜 について指摘せる如く ${ }^{9)}$ 端辺固定の影響は消失して雨端単純支承辺の場合に一致寸る事が予想される。而して其 の場合最小根は $P=1.5625$ であつた。如上の考察より $k \geqq 2$ なる任意の $k$ 個の径間数の連続板に対しては $\left(20^{\prime}\right)$ の最小根 $P$ は

$$
1.5625<P<2.5965
$$

と推定される。抆て図一2に見る如く $P$ の函数としての $\frac{T}{S}$ 曲線は上の領域では負值単調な增加函数を表わ している。從つて $\left(20^{\prime}\right)$ 式の左辺の採り得る負の最小值が此の場合の最小根 $P$ を与える事が解る。它の為には

$$
s=k-1
$$

と置かなくてはならない。従つて $\left(20^{\prime}\right)$ 式は次の如く書かれる・

$$
\cos \left(1-\frac{1}{2 k}\right) \pi=\frac{T}{S}
$$

上式より任意の $k$ (径間数)に対して $\frac{T}{S}$ の採る可き值が算出さ れるから逆に $\frac{T}{S}$-曲線[図一2]により其の時のPを読み取る事 が出来る。各種の $k$ の值に対する笑際の結果は表一 1 に示寸如 くである。佮上式に於て $k=\infty$ と怙壮 $\frac{T}{S}=-1$ となり $P=$ 1.5625 を得て当初の予想に一致する。即ち上の結果より径間 数の増加に伴い固定辺の影響は急速に減少して雨端単純支承辺 の場合に近付く有様が解る。

次に荷重 $q$ のみが作用する場合を考古よう。雨端単純支承の 場合同様此の場合る $y$ 万方に一波長形に挫屈する場合が最小挫 屈荷重に対応すると洘える事が出来る。即ち $m=2$ の場合に対する $\frac{T}{\mathrm{~S}}$ 曲線 表一1

\begin{tabular}{c|c|c|c}
\hline$k$ & $\left(1-\frac{1}{2 k}\right) \pi$ & $\cos \left(1-\frac{1}{2 k}\right) \pi$ & $P$ \\
\hline 2 & $3 / 4 \pi$ & -0.70711 & 1.853 \\
3 & $5 / 6 \pi$ & -0.86603 & 1.695 \\
4 & $7 / 8 \pi$ & -0.92388 & 1.637 \\
5 & $9 / 10 \pi$ & -0.95106 & 1.611 \\
6 & $11 / 12 \pi$ & -0.96593 & 1.597 \\
$\infty$ & $\pi$ & -1 & 1.5625 \\
\hline
\end{tabular}
[図一3]を用い，前記 $P$ の場合と同様の手続にてkの種々の值に対する $Q$ の最小根を求めれば表一 2 の結果を得る。此の場合る $k$ の増加に伴い固定端 の影響が急速に減少する事が解る。

c) 昺端固定辺の場合 此の場合は(21)式より

$$
\sin k \alpha=0
$$

これより

$$
\alpha=s \frac{\pi}{k}, \quad(s=0,1,2,3, \cdots \cdots \cdots, 2 k-1)
$$

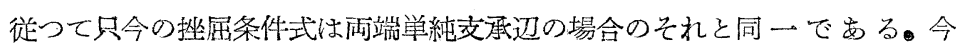
$b=\infty$ なる極限の場合を考光ると再び連続長杜の公式を得て其の最小根は此

\begin{tabular}{c|c|c}
\multicolumn{3}{|c}{ 表一2 } \\
\hline$k$ & $\cos \left(1-\frac{1}{2 k}\right) \pi$ & $Q[m=2]$ \\
\hline 2 & & 17.77 \\
3 & & 16.80 \\
4 & & \\
5 & 表一1 に同じ & 16.45 \\
6 & & 16.28 \\
$\infty$ & & 16.20 \\
\hline
\end{tabular}
の場合 $s=k-1$ と置いて求められる事が知られている10)。次に $k=1$ 即ち単一板の場合を考文よう・此の時 $s=0$ と招いてみれば挫届条件式 $\left(19^{\prime}\right)$ より

$$
\lambda_{1} \tanh \frac{\pi}{2} \lambda_{1}-\lambda_{2} \tanh \frac{\pi}{2} \lambda_{2}=0
$$

を得る。これは既知の公式である11。

8) S.Iguchi “Die Eigenwertprobleme für die elastishe rechteckige Platte," 北大工学部紀要 Vol.4, No.4, s.41。

9) Fr. Bleich 前掲萻 [註-4)] s.218 10） Fr. Bleich 前揭書 [註-4) $]$ s.217

11) S. Iguchi 前揭論交 [註-8)] s.44 
次に $k=2$ の場合には $s=1$ と扔いて $\left(19^{\prime}\right)$ 式より $\quad \lambda_{1} \operatorname{coth} \pi \lambda_{1}-\lambda_{2} \operatorname{coth} \pi \lambda_{2}=0$

を得る。これは $\left(20^{\prime \prime}\right)$ 式に他ならない。即ち一端固定辺他端単純支承辺なる单一板の挫属条件方程式である。今 斯かる単一板の挫屈撓曲形を 2 個互に単純支承端を突合せて逆対称形に接続したものは只今の連続板の挫屈撓曲 形となる事を注意すれば首肯される帰結である。上の二，三の特例に鑑み一般に此の場合の最小根は $\left(19^{\prime}\right)$ 式に 於て $s=k-1$ と置いて求められるであろ万事が推測される。

先づ荷重 $p$ のみが作用する場合を考光よう。先づ $k=2$ に対しては上述の如く其の最小根は $\left(20^{\prime \prime}\right)$ 式上り求め られて $P=2.5966$ であつた。又 $k=\infty$ に対しては前例同様 $P=1.5525$ と予想出来る。故に $k>2$ なる場合には

\section{$1.5625<P<2.5966$}

なる最小根の存在領域を設定し得る。扷て此の場合の挫屈条件式 $\left(19^{\prime}\right)$ 式の右边 $\frac{T}{S}$ は上記の領域で $P$ の負値学 調な増加函数なる事は図一 2 に見る如くであつて既述の如く $s=k$ と捛けばその最小根が求められる。然し斯く ては $\left(19^{\prime}\right)$ 式は径間数 $k$ に無関係となり Fr.Bleich が連続杜に於ける同様の重柄について説明せる如く ${ }^{12}$ )各径

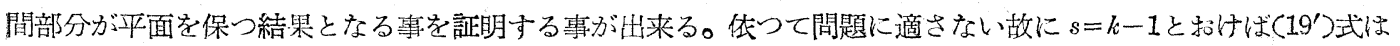

$$
\cos \left(1-\frac{1}{k}\right) \pi=\frac{T}{S}
$$

と書かれる。 $k$ の種々の值に対する上式の最小根は前例同様に して図一2の $\frac{T}{S}$ 一曲線により読み取る事が出来て表一了の結果 をを得る。侗兹に注意すべき事は上式に於て $k=2 k^{\prime}$ と置けば $\left(20^{\prime \prime \prime}\right)$ 式に一致して $k^{\prime}$ 個の径間数の一端固定辺他端単純支承 辺の連続板の最小挫屈荷重は $2 k^{\prime}$ 個の径間数の雨端固定辺の連 続板のそれに等しい事となる。此れは前者の撓屈撓曲形を 2 個 互に単純支承端辺を突合せて逆対称形に接続すれば後者の挫屈 形に他ならない事を注意すれば了承される。又 $k=\infty$ とすれば 此の場合る $\frac{T}{S}=-1$ を得るから $P=1.5625$ となり径間数の増 加に伴い固定端の影響が消失するに至る事が解る。

次に荷重 $q$ のみが作用する場合には前例同様 $m=2$ の場合が Qの最小值を与える事は容易に推測出来るから図一ろにより表 -4の結果を得る。此の場合すkの堌加に伴い固定端の影響が 速かに減少する慗が解る。

\begin{tabular}{c|c|c|c}
\multicolumn{3}{c}{ 表一3 } \\
\hline$k$ & $\left(1-\frac{1}{k}\right) \pi$ & $\cos \left(1-\frac{1}{k}\right) \pi$ & $p^{\prime}$ \\
\hline 2 & $\frac{1}{2} \pi$ & 0 & 2.5966 \\
3 & $\frac{2}{3} \pi$ & -0.50000 & 2.062 \\
4 & $\frac{3}{4} \pi$ & -0.70711 & 1.853 \\
5 & $\frac{4}{5} \pi$ & -0.80902 & 1.752 \\
6 & $\frac{5}{6} \pi$ & -0.86603 & 1.695 \\
$\infty$ & $\pi$ & -1 & 1.5625 \\
\hline
\end{tabular}

d) 一端自由辺他端単純文承辺の場合 先づ後の計算の便宜上(22)式を逆 数の形に書いて置く。即ち

$$
\left.\begin{array}{rlrl} 
& \frac{\sin (k-1) \alpha}{\sin k \alpha} & =\frac{S T^{\prime}}{\bar{S} S^{\prime \prime}} \\
\text { 一方（6)より } & \cos \alpha=\frac{T}{S}
\end{array}\right\}
$$

\begin{tabular}{|c|c|c|}
\hline \multicolumn{3}{|c|}{ 表一 4} \\
\hline$k$ & $\cos \left(1-\frac{1}{k}\right) \pi$ & $Q[m=2]$ \\
\hline 2 & & 22.96 \\
\hline 3 & & 19.15 \\
\hline 4 & 量ー○に同ば & 17.77 \\
\hline 5 & & 17.14 \\
\hline 6 & & 16.80 \\
\hline$\infty$ & ${ }^{\circ}$ & 16 \\
\hline
\end{tabular}

上式は $\alpha$ を parameter とする挫屈条件式と考光る事が出来る。今 $k=1$ と 置いてみると第 1 式左辺の分子は 0 となるから右辺の分子も 0 亿等置しなく てはならない。然る時は第2式を参照して結局

$$
\bar{T}^{\prime}=\frac{\gamma_{1}+P \lambda_{1}}{\beta_{1}} \operatorname{coth} \pi \lambda_{1}-\frac{\gamma_{2}+P \lambda_{2}}{\beta_{2}} \operatorname{coth} \pi \lambda_{2}=0
$$

とすべきである。此れは単一板の公式である䈏で特に荷重 $p$ のみが作用する場合には上式の最小根は

$$
P=0.5107
$$

と求められる。又荷重 $q$ のみが作用し $p$ が存在しなければ。

と書く事が出来るから前式より值ちに

$$
\gamma_{1}=-\lambda_{1} \beta_{2}, \quad \gamma_{2}=-\lambda_{2} \beta_{1}
$$

$$
\lambda_{2} \beta_{1}^{2} \tanh \pi \lambda_{1}=\lambda_{1} \beta_{2}^{2} \tanh \pi \lambda_{2}
$$

を得て既知の公式 ${ }^{13)}$ に一致する。

双て訫算例として先づ荷重 $p$ のみが作用省場合を考えよう。 $k=1$ なら前述の如く $P=0.5107$ である。 
次に $k=\infty$ に対する $P$ を求める為に $\left(22^{\prime}\right)$ の第 1 式左辺を次の如く変形する。

$$
\frac{\sin (k-1) \alpha}{\sin k \alpha}=\cos \alpha-\cot k \alpha \sin \alpha
$$

今 $\alpha=i \alpha^{\prime}$ と悸き $\lim _{k \rightarrow \infty} \operatorname{coth} k \alpha^{\prime}=1$ なる事を考慮すれば

$$
\begin{aligned}
& \lim _{k \rightarrow \infty} \frac{\sin (k-1) \alpha}{\sin k \alpha}=\lim _{k \rightarrow \infty}\left(\cosh \alpha^{\prime}-\operatorname{coth} k \alpha^{\prime} \sinh \alpha^{\prime}\right) \\
= & \cosh \alpha^{\prime}-\sinh \alpha^{\prime}=\frac{T}{S} \pm \sqrt{\frac{T^{2}}{S^{2}}-1} \quad \text { 但L } \quad \cos \alpha=\cosh \alpha^{\prime}=\frac{T}{S}
\end{aligned}
$$

故に $k=\infty$ に対する最小根は

$$
\frac{S T^{\prime}}{\bar{S} S^{\prime \prime}}=\frac{T}{S} \pm \sqrt{\frac{T^{2}}{S^{2}}-1}
$$

より求められ $P=0.5967$ を得る故に任意の $k$ に対しては

$$
0.5107<P<0.5967
$$

と予想出来る。従つて上の領域で $P$ に対寸る $\frac{T}{S}, \frac{S T^{\prime}}{\bar{S} S^{\prime \prime}}$ の函数值を計算して执けば

$$
\cos \alpha=\frac{T}{S}, \quad \sin \alpha=i \sqrt{\left(\frac{T}{S}\right)^{2}-1}
$$

の值か誩算されるから，例えば

$$
\sin n \alpha=2 \cos \alpha \sin (n-1) \alpha-\sin (n-2) \alpha
$$

なる漸化式により任意の $k$ に対する $\frac{\sin (k-1) \alpha}{\sin k x}$ の函数值を算出する事が出来る。故に挫属条件式の根 $P$ は $\frac{S T^{\prime}}{\bar{S} S^{\prime \prime}}$-曲線と $\frac{\sin (k-1) \alpha}{\sin k \boldsymbol{\alpha}}$-曲線との交点より図式に読久取る事が出来る。只今の場合表一 5 の結果を得る。即ち 径間数の増加に伴い極めて迅速に一定の極限值に近付くが両端単純支承辺の場合とは一致しない事が解る。

今度は荷重 $q$ の及が作用寸る場合を考古よう。先づ $k=2$ なる場合は連続板は 1 長辺自由残りの 3 辺単純支 承の単一板と 4 辺単純支承の単一板との結合されたるの と見做され，夫々辺比 $\frac{a}{b}=\frac{1}{2}$ であるから前者が $y$ 方

\begin{tabular}{c|ccccc}
\multicolumn{7}{c}{ 表一 5} \\
\hline$k$ & 1 & 2 & 3 & 4 & $\infty$ \\
\hline$P$ & 0.5107 & $0.591_{5}$ & $0.596_{3}$ & $0.596_{7}$ & 0.5967 \\
\hline
\end{tabular}
向に半波長形に挫屈寸る場合は $Q=2.672$,一波長形に挫屈する場合には $Q=5.610$ であつて, 後者が $y$ 方向に 半波長形に挫屈する場合は $Q=25$, 一波長形に挫屈寸る場合は $Q=16$ なる結果が既知である。依つて只今の 2 径 間連続板に対しては $y$ 方向へ半波長形に挫属する場合には

$$
2.672<Q<25
$$

となるべく，一波長形に挫屈する場合は［区別の為此の場合の根を $Q^{\prime}$ と記す］

\section{5. $610<Q^{\prime}<16$}

と予想し得る。然るに上の両限界より $Q, Q^{\prime}$ の大小関係 を判断する事は出来ないから凮者の場合につき吟味比較 しなくてはならない。前同様 $\frac{S T}{\bar{S} S^{\prime \prime}}$ 一曲線と $\frac{\sin (k-1) \alpha}{\sin k x}$ 一曲線との交点より最小限Qを読みとればよい。尙 $k=\infty$ なる極限に対しては此の場合る（25）の関係式が成立す る。其の手数は図一 4 に示寸如くである。但し同図に於 ては前記雨曲線は便宜上その逆数を示してある。省此の 時 (25) 右辺の複号の各場合は互に送数関係にあるから 計算上特別の手数は要さない。而も事奉上それば $k=4$ に 対する $\frac{\sin k a}{\sin (k-1) a}$ - 曲線に一致する。拟て害際の結果は 表一6 の如くである。即ち最小挫屈荷重は $y$ 方向に半波 長形に挫屈寸る場合に対応する事が解る。因久に前記 $Q$ の試索限界では $\frac{T}{S}<-1$ となり從つて $\cos \alpha<-1$ なる 事となり奇異の観があるが，元来 $\boldsymbol{\alpha}$ は単なる parameter であつて最後に消去さるべき性質のるのであるから其の 值の如何は問題とはならないのである。

\section{図一}
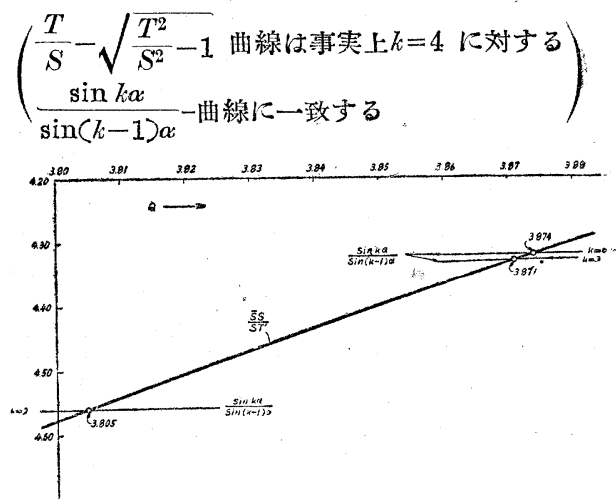

表一 6

\begin{tabular}{c|ccccc}
\hline$k$ & \multicolumn{1}{c|}{1} & \multicolumn{1}{c}{2} & \multicolumn{1}{c}{3} & \multicolumn{1}{c}{4} & \multicolumn{1}{c}{$\infty$} \\
\hline$[m=1] Q$ & 2.6722 & 3.805 & 3.871 & 3.874 & 3.874 \\
{$[m=2] Q^{\prime}$} & 5.61 & 6.06 & 6.05 & 6.05 & 6.05 \\
\hline
\end{tabular}


e）二端自由辺他端固定辽の場合 此の場合は(23)式より

又(6)より

$$
\left.\begin{array}{rl}
\frac{\cos (k-1) \alpha}{\cos k \alpha} & =\frac{S T^{\prime}}{\overline{S S^{\prime \prime}}} \\
\cos \alpha & =\frac{T}{S}
\end{array}\right\}
$$

上式は $\alpha$ を parameter とする挫屈条件方程式である。双て単一板に対しては $k=1$ と括けば上の両式より直ち に次式を得る。

$$
T T^{\prime}=\bar{S} S^{\prime \prime}
$$

或いは $\left\{\lambda_{1} \operatorname{coth} \pi \lambda_{1}-\lambda_{2} \operatorname{coth} \pi \lambda_{2}\right\}\left\{\frac{\gamma_{1}+P \lambda_{1}}{\beta_{1}} \operatorname{coth} \pi \lambda_{1}-\frac{\gamma_{2}+P \lambda_{2}}{\beta_{2}} \operatorname{coth} \pi \lambda_{2}\right\}$

$$
=\left\{\frac{\lambda_{1}}{\beta_{1}} \operatorname{cosech} \pi \lambda_{1}-\frac{\lambda_{2}}{\beta_{2}} \operatorname{cosech} \pi \lambda_{2}\right\}\left\{\left(\gamma_{1}+P \lambda_{1}\right) \operatorname{cosech} \pi \lambda_{1}-\left(\gamma_{2}+P \lambda_{2}\right) \operatorname{cosech} \pi \lambda_{2}\right\}
$$

今上式の両辺を $\frac{\gamma_{1}+P \lambda_{1}}{\beta_{1}} \operatorname{coth} \pi \lambda_{1}$ で割つて $b=\infty$ なる極限を考えてみる。此の時

$$
\left.\left.\left.\begin{array}{l}
\lambda_{1}=0 \\
\lambda_{2}=i \vee \bar{P}
\end{array}\right\} \quad \begin{array}{l}
\beta_{1}=0 \\
\beta_{2}=-P
\end{array}\right\} \quad \begin{array}{l}
\gamma_{1}=0 \\
\gamma_{2}=-i P \vee \bar{P}
\end{array}\right\}
$$

なる事を考慮すれば上式は結局次の如くなる。

$$
\frac{1}{\pi}-\sqrt{P} \cot \pi V \bar{P}=\frac{1}{\pi} \quad \text { これより } \quad \cot \pi \sqrt{P}=0
$$

此の式の最小根は $\pi V \bar{P}=\frac{\pi}{2}$, 従つて $P=\frac{1}{4}$ 或いは $p=\frac{\pi^{2} D}{4 a^{2}}$ を得る。これは長さ $a$ なる一端固定他端自 由なる長杜の挫屈荷重に他ならない。荷重 $q$ のみが作用し $p$ が存在せぬ場合には

$$
\gamma_{1}=-\lambda_{1} \beta_{2}, \quad \gamma_{2}=-\lambda_{2} \beta_{1}
$$

と書く事が出来るから(26)式より容易に次式を導き得る。

$$
-2 \beta_{1} \beta_{2}+\left(\beta_{1}{ }^{2}+\beta_{2}^{2}\right) \cosh \pi \lambda_{1} \cosh \pi \lambda_{2}=\frac{\lambda_{1}^{2} \beta_{2}{ }^{2}+\lambda_{2}{ }^{2} \beta_{1}^{2}}{\lambda_{1} \lambda_{2}} \sinh \pi \lambda_{1} \sinh \pi \lambda_{2}
$$

此れは既知の単一板の公式に他ならない14)。

双て計算例として先づ $p$ のみが作用する場合を考えよ5。 $k=1$ なら 1 長辺自由他の長辺固定残りの 2 辺単純支 承の単一板となり其の最小根は $P=0.6565$ である。次に $k=\infty$ に対しては $\alpha=i \alpha^{\prime}$ と执いて $\lim _{k \rightarrow \infty} \tanh k \alpha^{\prime}=1$ な る事を考慮すれば

$$
\lim _{k \rightarrow \infty} \frac{\cos (k-1) \alpha}{\cos k \alpha}=\lim _{k \rightarrow \infty}\left(\cosh \alpha^{\prime}-\tanh k \alpha^{\prime} \sinh \alpha^{\prime}\right)=\cosh \alpha^{\prime}-\sinh \alpha^{\prime}=\frac{T}{S} \pm \sqrt{\frac{T^{2}}{S^{2}}-1}
$$

と書かれるから此の場合す $P$ は(25)式より求められて $P=0.5967$ である。故に

$$
0.5967<P<0.6565
$$

の領域で $\frac{S T^{\prime}}{\bar{S} S^{\prime \prime}}$ 一曲線と $\frac{\cos (k-1) \alpha}{\cos k \alpha}$-曲線との交点よりPの値を読みとれば表一 7 の結果を得る。

次に荷重 $g$ みが作用する場合を考えよう。先づ $k=2$ の場合は前例 表一 6 と比較して只今の場合は $Q>3.805$

と予想され又 $k=\infty$ に対しては既述の如く(25)式が用い られ $Q=3.874$ である。故に $k \geqq 2 な る$ 任意の $k$ に対して は最小根 $Q$ は

$$
3.805>Q>3.874
$$

の領域で求められる事が解る。而して害際の数値的結果 は表一8 の如くでせる。

\begin{tabular}{c|ccccc}
\hline \multicolumn{7}{c}{ 表 -7} \\
\hline$k$ & 1 & 2 & 3 & 4 & $\infty$ \\
\hline$P$ & 0.6565 & $0.601_{8}$ & $0.597_{0}$ & 0.5967 & 0.5967 \\
\hline \multicolumn{7}{c}{ 表一 8} \\
\hline$k$ & 1 & 2 & 3 & 4 & $\infty$ \\
\hline$[m=1] Q$ & 5.344 & 3.946 & 3.878 & 3.874 & 3.874 \\
\hline
\end{tabular}

今表一 5 , 欢び表一6を夫及表一7 及び表一8 に比較すれば前者にあつては増加数列, 後者にあつては減少数列 として共に同一極限值に収歛する有様が解る。而も径間数が大凡 4 以上になると自由辺の影響は存続するが他の 端辺が単純支承なるか固定なるかの羑異は事実上消隇することとなる。

i) 両端自由辺の場合，此の場合は(24)式より 
又(6)式より

$$
\left.\begin{array}{rl}
\frac{\sin (k-2) \alpha}{\sin (k-1) \alpha \pm \sin \alpha} & =\frac{S T^{\prime}}{\bar{S} S^{\prime \prime}} \\
\cos \alpha & =\frac{T}{S}
\end{array}\right\}
$$

即ち上式は $a$ を parameter とする挫屈条件式である。只今の場合は $k=1$ と置いて単一板に対する公式を誘導す る事は出来ない。此の事は一般解並びに端辺条件の誘導に際し中間支承辺又は端辺に於ける撓み 0 なる条件が基 本的に利用されているに拘らず，両端自由辺なる単一板にあつては斯かる端辺が存在しない事に起因するるので $k=1$ と置く事が無意味なる事が了承されよ $5 。 k=2$ と抢けば 2 徍間の場合で ( $\left.24^{\prime}\right)$ 第 1 式左辺に於いて上昂を 採れば左辺は 0 となるから(22')式に於ける $k=1$ の場合同様

$$
T^{\prime}=0
$$

を得る。此の結果は 1 長辺自由残りの 3 辺単純交承の 単一板の挫屈撓曲形を 2 個単純交承の長辺を亘に突合せて逆対称形に接続したものが只今の場合の逆対 称挫屈形に相当する事を注意すれば首肯される(図一5(a))。

又 $\left(24^{\prime}\right)$ 第 1 式左辺に於いて下号を採れば $\frac{0}{0}$ とり不定形となるから $k=2+\varepsilon$ と置いて $\varepsilon \rightarrow 0$ としてみる。即ち左辺は

$$
\lim _{\varepsilon \rightarrow 0} \frac{\sin \varepsilon \alpha}{\sin (1+\varepsilon) \alpha-\sin \alpha}=\frac{1}{\cos \alpha}
$$
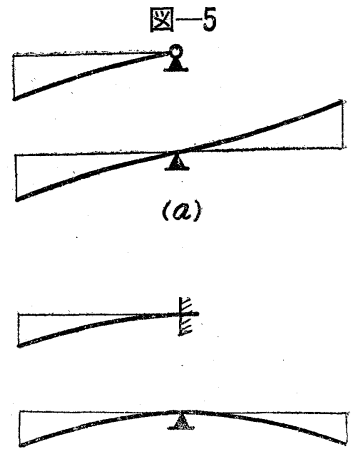

(b)

となり第 2 式を共に考慮すれば (23') 式に於けるk=1の場合同様值ちに(26)式 に到達する。此の結果は 1 長辺自由他の長辺国定の単一板の挫届撓曲形を 2 個 固定辺を互に突合せて正対称形に接続したものが只今の場合の正対称挫属形に相当する事を注意すれば了承され る処である(図一5(b))。

一般に径間数が偶数個なる場合を考えるに環境条件の対称性により，挫屈形は中央支持辺に関して逆対称形及 び正対称形の 2 種の場合が考えられる。前者の場合中央交持辺に於ける撓曲面の形状は図一5(a)型，後者の場合

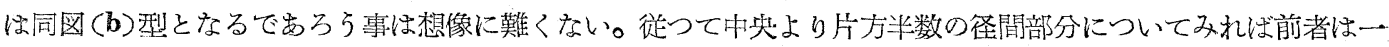
端自由辺他端単純支承辺の連続板として，後者は一端自由辺他端固定辺の連続板として挫屈せるるのと見做す事 が出来る。此の事は次の如く証明される。今径間数を $2 k^{\prime}$ とし(24')第1 式左辺に於いて $k=2 k^{\prime}$ と扔けば

$\frac{\sin (k-2) \alpha}{\sin (k-1) \alpha \pm \sin \alpha}=\frac{\sin \left(2 k^{\prime}-2\right) \alpha}{\sin \left(2 k^{\prime}-1\right) \alpha \pm \sin \alpha}=\frac{2 \sin \left(k^{\prime}-1\right) \alpha \cos \left(k^{\prime}-1\right) \alpha}{\sin k^{\prime} \alpha \cos \left(k^{\prime}-1\right) \alpha+\cos k^{\prime} \alpha \sin \left(k^{\prime}-1\right) \alpha \pm \sin \alpha}$

しかるに

なる関係を㕍慮すれれば

$$
\cos k^{\prime} \alpha \sin \left(k^{\prime}-1\right) \alpha+\sin \alpha=\sin k^{\prime} \alpha \cos \left(k^{\prime}-1\right) \alpha
$$$$
\sin k^{\prime} \alpha \cos \left(k^{\prime}-1\right) \alpha-\sin \alpha=\cos k^{\prime} \alpha \sin \left(k^{\prime}-1\right) \alpha
$$

$$
\frac{\sin (k-2) \alpha}{\sin (k-1) \alpha \pm \sin \alpha}=\left\{\begin{array}{l}
\frac{\sin \left(k^{\prime}-1\right) \alpha}{\sin k^{\prime} \alpha}: \text { 左辺上昂に対し } \\
\frac{\cos \left(k^{\prime}-1\right) \alpha}{\cos k^{\prime} \alpha}: \text { 左辺下号に対し }
\end{array}\right.
$$

と書か和るから結局 $\left(24^{\prime}\right)$ は第1式の左辺複昂

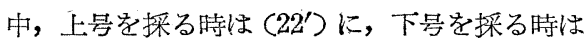
( $\left.23^{\prime}\right)$ に一致する事が解る。双てkが偶数な らば $\left(24^{\prime}\right)$ 第1式左辺複昂中上号は逆対称形 挫屈に，下号は正対形挫屈に対応する事は上に 見た通りであるが，此の事は一般に $k$ の奇偶に 拘らず成立する事を証する事が出来る（証明省 略)。

計算例については上述せる処より径間数が偶 数個なる場合，逆対称形挫屈に対しては表一-5 並びに表一6の結果が, 正対称形挫屈に対して は表一7並びに表-8 の結果が其の嫿該当する。 但し此等の表中の 径間数 $k$ は只今の場合 $2 k$ としなくてはならない。文 $k=\infty$ に対しては $\alpha=i \alpha^{\prime}$ と置いて前同様
図一6図中,正,斜と記してあるのは夫々正対称形 挫屈, 逆対称形挫屈に対応するの意である

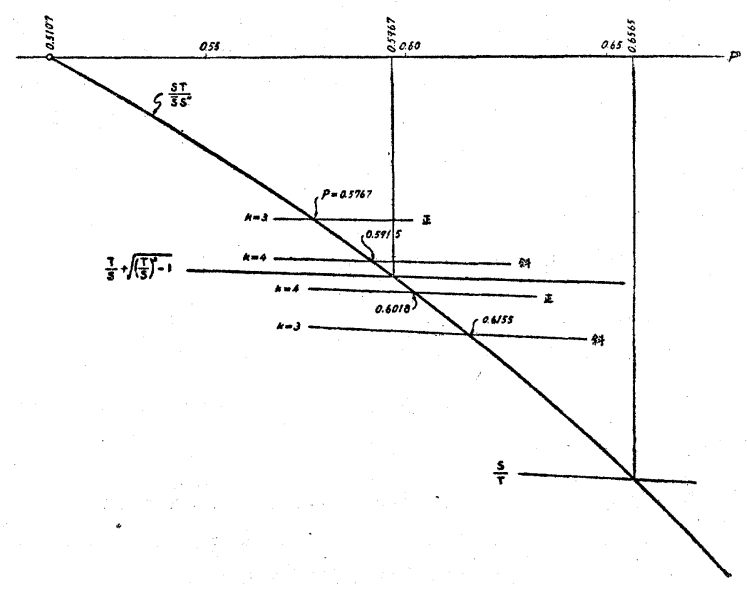




$$
\lim _{k \rightarrow \infty} \frac{\sin (k-2) \alpha}{\sin (k-1) \alpha \pm \sin \alpha}=\cosh \alpha^{\prime}-\sinh \alpha^{\prime}=\frac{T}{S} \pm \sqrt{\frac{T^{2}}{S^{2}}-1}
$$

なる関係を得るから此の場合る（25）式を得て挫剭荷重は前記各表中に与えるるのに一致する事が解る。径間数 が奇数なる場合に対しては直接 $\left(24^{\prime}\right)$ 第1式の両辺を夫々 $P$ 文は $Q$ の函数として図示し，両曲線の亲点より 求むる $P$ 文は $Q$ の值を読みとるのである。図一6は荷重 $p$ のが作用する場合の根 $P$ の図式試索の有様を示 したもので，同図中 $k$ が偶数である如き場合に対する作図は表一 5 及び 表一7に示寸半数の徍間数の場合の作図 に他ならない。実際の数值的結果は表-9, 表一10 の如くである。

表一9 荷重 $\boldsymbol{p}$ のみが作用する場合の $\boldsymbol{P}$ の值

\begin{tabular}{|c|c|c|c|c|c|c|}
\hline$k$ & 2 & 3 & 4 & 5 & 6 & $\infty$ \\
\hline 逆対称形挫蟨 & 0.5107 & $0.615_{5}$ & $0.591_{5}$ & $0.598_{2}$ & $\underline{0.596_{3}}$ & \multirow{2}{*}{$\underline{0.5967}$} \\
\hline 正対称形挫屈 & 0.6565 & $\underline{0.576_{7}}$ & 0.6018 & $\underline{0.595_{5}}$ & $0.597_{0}$ & \\
\hline \multicolumn{7}{|c|}{ 表- 10} \\
\hline$k$ & 2 & 3 & 4 & 5 & 6 & $\infty$ \\
\hline 逆対称形挫屈 & 2.673 & 4.190 & 3.805 & 3.890 & 3.871 & \multirow{2}{*}{3.874} \\
\hline 正対称形挫屈 & 5.344 & 3.580 & 3.946 & 3.855 & 3.878 & \\
\hline
\end{tabular}

上表より挫屈荷雷は径間数が偶数なる時は逆対称形挫属に 奇数個なる時は正対称形挫屈に対応する事が解る。図一7は 此等の撓曲形を $x$ 方向の断面に㳂つて図解したるのである。 双て上揭各表より大凡 $3 \sim 4$ 径間以上では $P$ 或いは $Q$ は殆

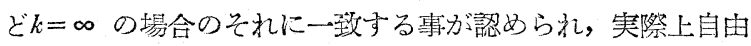
端辺を有与る多径間連続板の挫虽荷重は会式(25)より求めら 礼ると言ら事が出来る。

\section{結言}

要するに本交は所題の如き等徍間連続板の挫屈荷重は階差 万程式の解法を利用して求める事が出来，任意の径間数に対 する挫屈荷重を一挙に求め得る便宜がある事宗示し，大抵の
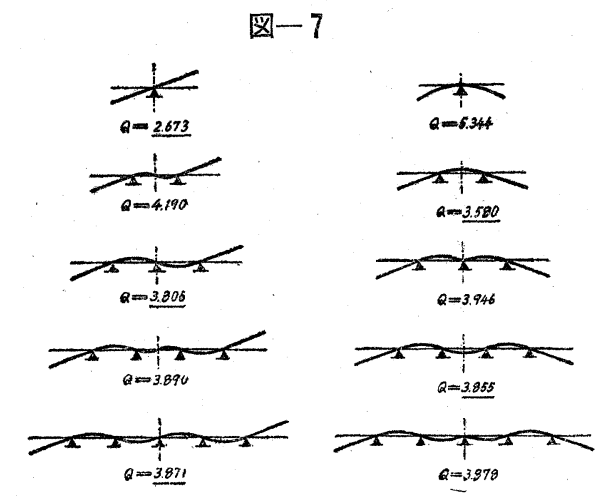
場合 3〜4 径間以上ては径間数無限なる極限の場合の挫屈荷重を以て当てるも実際上差交党ない事を明らかにし たものと考光られる。

佮本計算法の応用の直接の拡張として直ちに考えられる事は所題の如き連続板が $y$ 軸方向にも $r$ 個接続する如 き場合[図一8]への適用であつて,此れは容易に解る如く本交に言 板を $y$ 方向にも等間隔に $r-1$ 個の $x$-軸に平行なる中間単純支承辺を以 て支持したるのに他ならない。即ち挫屈撓曲形を想定すれば $y$ 方向の各 径間は順次交互に区対側一逆対称形に撓曲接続する篦だから当該中間支 承辺に於ける $y$ 方向の曲げモーメントは０である。従つてその一径間部 分に着目すれば本文にて詳述せる連続板の挫屈形であつて結局問題はy 方向の径間中の一つのみにつき $x$ 方向に連続する連続板として取技えば 足りる事となる。此れは文 $x$ 軸に淔交する両端辺が単純支承ならば $x$ 方 向の径間中の任意の一つにつき $y$ 方向に連続する連続板として取扱ら事 も出来る訳でもる。実用上からは径間数の相当多い時は自由端辺が存在 しなければ端辺はすべて単純支承と見做してよい事は本交に示した通り

\section{図-8}

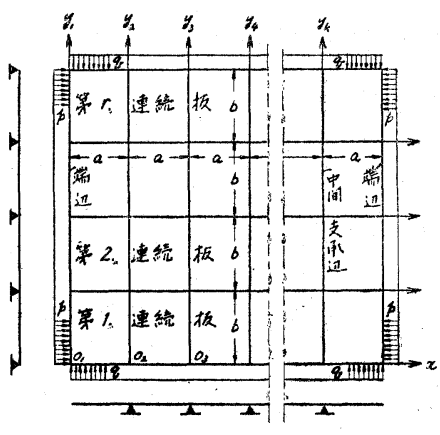
であるから, 斯かる場合は結局 $x, y$ 両方向の径間で仕切られる一格子目内を周辺単純支承の単一板として取扱 のみでよい事となる。然し自由端辺の存する时はその自由端辺を端辺とする力向の一帯状部分を連続板として本 交中の公式(25)により挫屈荷重を求めなければならない。佮本交はさきに井口鹿象博士指導の下に行つた “矩形 組合板の挫屈理論”の一部であつて交部省科学研究費の援助を受けた。記して深謝の意を表する。 